\title{
HUBUNGAN PERSEPSI TENTANG PERAN ORANG TUA DENGAN PERILAKU SEKSUAL REMAJA DI SMP KABUPATEN PASAMAN
}

\author{
Dewi Susanti, Alsri Windra Doni, Lora Fazira \\ (Poltekkes Kemenkes Padang)
}

\begin{abstract}
Parents as the first and foremost educators in the family have a very complex role. Lack of parental role can make adolescents fall into risky sexual behavior (RSB). RSB will have a negative impact on adolescents such as physical, psychological and social impacts. The purpose of this study was to examine the relationship between perceptions of the parents role and adolescent sexual behavior in the Pasaman District Junior High School. This type of research is an analytic survey with a cross sectional design. The study was carried out from January to March 2020 at 36 schools spread across 12 sub-districts taken by stratifield random sampling of 324 students. The instrument uses a standardized questionnaire that is valid and reliable. Data analysis with chi square with 95\% confidence interval and $p$ value < 0.05. In the study, it was found that the RSB of adolescents was $58,44 \%$ and the negative perception of the parents role was $53,2 \%$. There is a relationship between perceptions of the parents role with RSB in adolescents ( $p$ value 0.001). Adolescents who have a negative perception of the parents role tend to have risky sexual behavior. It is recommended to the $B K K B N$ to improve the BKR program to provide educational materials that are tailored to the educational level of parents. Creating a family empowerment program by integrating sexual education in the family.
\end{abstract}

Keywords: perception; parents role; sexual behavior; adolescents

\begin{abstract}
Abstrak
Orang tua sebagai pendidik pertama dan utama dalam keluarga memiliki peranan yang sangat kompleks. Kurangnya peran orang tua dapat membuat remaja jatuh pada perilaku seksual beresiko. Perilaku seksual beresiko akan menimbulkan dampak negatif terhadap remaja seperti dampak fisik, psikologis dan sosial. Tujuan penelitian ini adalah untuk melihat hubungan persepsi tentang peran orang tua dengan perilaku seksual remaja di Sekolah Menengah Pertama Kabupaten Pasaman. Jenis penelitian ini survey analitik dengan rancangan cross sectional. Penelitian dilaksanakan Januari sampai Maret 2020 pada 36 sekolah yang tersebar di 12 Kecamatan yang diambil secara stratifield random sampling sebanyak 324 siswa. Instrument menggunakan angket terstandar yang valid dan reliabel. Analisis data dengan chi square dengan derajat kepercayaan $95 \%$ dan nilai $p$ value $<0,05$. Pada penelitian didapatkan perilaku seksual beresiko pada remaja yaitu $58,44 \%$ dan persepsi tentang peran orang tua yang negatif yaitu 53,2\%. Terdapat hubungan persepsi tentang peran orang tua dengan perilaku seksual berisiko pada remaja ( $p$ value 0,001 ). Remaja yang memiliki persepsi negatif tentang peran orang tuanya cenderung berperilaku seksual berisiko. Disarankan kepada BKKBN agar dapat meningkatkan program BKR untuk menyedikan materi edukasi yang disesuaikan dengan tingkat pendidikan orang tua. Membuat program pemberdayaan keluarga dengan mengintegrasikan pendidikan seksual dalam keluarga.
\end{abstract}

Kata Kunci: Persepsi; peran orang tua; perilaku seksual; remaja

\section{PENDAHULUAN}

Masa remaja merupakan masa peralihan dari anak-anak menuju dewasa, yang ditandai oleh perubahan-perubahan fisik yang mendahului kematangan seksual. ${ }^{1}$ Seiring dengan 
perubahan tersebut, remaja cenderung mengalami permasalahan terkait kesehatan reproduksinya. Masalah yang paling menonjol adalah triad KRR (Tiga resiko dalam kesehatan reproduksi remaja), seperti Seks bebas, HIV/AIDS (Human Imunodeficiency Virus/ Acquired Immuno Deficiency Syndrome), Napza (Narkotika, Alkohol, Psikotropika dan Zat Aditif lainnya). Dalam kaitan dengan seksualitas, remaja cenderung untuk jatuh pada perilaku seksual beresiko. Perilaku seksual yang beresiko dapat menimbulkan masalah kesehatan bagi remaja. ${ }^{2}$

Menurut WHO (World Health Organization) tahun 2016 menyebutkan bahwa sekitar 21 juta remaja perempuan yang berumur 15-19 tahun di negera berkembang, mengalami kehamilan setiap tahun dan hampir setengah kehamilan tersebut (49\%) merupakan kehamilan yang tidak di inginkan. kehamilan tersebut salah satunya disebabkan oleh adanya perilaku seks menyimpang, kurangnya pengetahuan, nilai-nilai sosial atau budaya. ${ }^{3}$ Perilaku seksual merupakan segala tingkah laku yang didorong oleh hasrat seksual, baik dengan lawan jenisnya maupun sesama jenis. ${ }^{4}$

Berdasarkan SKRRI (Survey Kesehatan Reproduksi Remaja Indonesia) tahun 2017 menunjukkan pengalaman berpacaran remaja di Indonesia cenderung semakin berani dan lebih terbuka yaitu; 1. Berpegangan tangan, laki-laki 75\% dan perempuan 64\%, 2 . Berpelukan laki-laki 33\% dan perempuan 17\%, 3. Berciuman laki-laki 50\% dan perempuan $30 \%$, 4. Meraba/merangsang laki-laki $22 \%$ dan perempuan $5 \%$, 5. Hubungan seksual lakilaki $8 \%$ dan perempuan $2 \%$. Di antara laki-laki dan perempuan terdapat $12 \%$ kehamilan yang tidak diinginkan dilaporkan oleh perempuan dan $7 \%$ oleh laki-laki yang mempunyai pasangan dengan kehamilan yang tidak diinginkan. $23 \%$ perempuan dan $19 \%$ pria mengetahui teman mereka melakukan aborsi. ${ }^{5}$

Seiring dengan perkembangan zaman, remaja Indonesia semakin beresiko terhadap ancaman perubahan tatanan kehidupan seperti perilaku seks menyimpang. Perubahan yang terjadi pada tatanan kehidupan tradisional menjadi modern menyebabkan remaja sangat rentan terhadap tekanan baik tekanan emosi, mental, maupun sosial, sehingga sering mengalami perubahan jati diri. Dampak dari perilaku seks menyimpang diantaranya kehamilan yang tidak diinginkan (KTD), aborsi, terjangkitnya penyakit menular seksual (PMS) dan HIV/AIDS (Human Imunodeficiency Virus/ Acquired Immuno Deficiency Syndrome) serta masalah kesehatan lainnya. ${ }^{6}$

Survei Demografi Kesehatan Indonesia Remaja (SDKI) tahun 2017 menyebutkan bahwa sebanyak $11 \%$ perempuan dan $7 \%$ laki-laki yang pasangannya mengalami kehamilan yang tidak diinginkan, sebanyak $52 \%$ laki-laki dan $15 \%$ perempuan belum kawin usia 15-24 tahun memilih untuk menggugurkan kandungan, meskipun $29 \%$ laki-laki dan 39 $\%$ perempuan diumur yang sama masih memilih untuk melanjutkan kehamilannya. ${ }^{7}$ Berdasarkan laporan Kementerian Kesehatan RI Triwulan II tahun 2019 secara kumulatif 
terdapat 117.064 kasus AIDS (Acquired Immuno Deficiency Syndrome) dan 349.882 kasus HIV (Human Imunodeficiency Virus) positif, yang penularannya melalui hubungan seks beresiko sebanyak $70.2 \%{ }^{8}$

Salah satu penyebab penyimpangan perilaku seksual remaja yaitu kurangnya dukungan, perhatian, dan pengawasan dari orang tua. Orang tua mempunyai peran yaitu membantu remaja dalam meningkatkan rasa percaya diri dan mengajarkan remaja membuat keputusan agar tidak terpengaruh dengan teman-temannya. Tugas orang tua juga mengawasi perkembangan anak agar tidak terjerumus ke dalam hal-hal yang tidak diinginkan. Beberapa peran orang tua yaitu sebagai pendidik, panutan, pendamping, konselor, komunikator. ${ }^{9}$

Tujuan penelitian ini adalah untuk melihat hubungan persepsi tentang peran orang tua dengan perilaku seksual remaja di Sekolah Menengah Pertama Kabupaten Pasaman. Sikap atau perlakuan orang tua mempunyai pengaruh yang sangat besar terhadap perkembangan dan pembentukan pribadi anak menuju remaja. Namun, yang sering terjadi orang tua kurang memperhatikan anak dalam kebutuhan yang satu dengan yang lain. Sehingga sering menimbulkan masalah kasih sayang yang dibutuhkan anak tidak hanya terpenuhinya seluruh kebutuhan fisik-material, tetapi juga kebutuhan fisik sosial-psikologisnya. ${ }^{10}$

\section{METODE PENELITIAN}

Jenis penelitian ini adalah penelitian survey analitik dengan rancangan cross sectional. Dilaksanakan di SMP Kabupaten Pasaman. Data dikumpukan dari bulan Januari sampai Maret 2020. Populasi adalah seluruh remaja SMP di Kabupaten Pasaman yang tersebar di 12 Kecamatan yang diambil secara stratifield random sampling sebanyak 324 siswa.

Populasi pada penelitian ini adalah seluruh siswa SMP di Kabupaten Pasaman dan sampel diambil secara stratified random sampling sebanyak 324 orang. Kriteria insklusi adalah siswa SMP yang tinggal bersama orang tua. Instrumen dalam penelitian ini menggunakan angket sebagai alat ukur, yang terdiri dari: Kuesioner perilaku seksual remaja yang terdiri dari 15 item yaitu 7 item merupakan perilaku seksual tidak beresiko dan 8 item perilaku seksual beresiko. Kuesioner tersebut merupakan kuesioner baku yang diambil dari "Muflih \& Endang Nurul Syafitri dalam Jurnal Keperawatan respati Yogyakarta tahun 2018". ${ }^{11}$ Kuesioner persepsi tentang peran orang tua yang terdiri dari 20 item. Kuesioner tersebut merupakan kuesioner yang dikembangkan sendiri oleh peneliti. Sebelum penelitian dilakukan, instrument penelitian yang digunakan untuk pengambilan data telah dilakukan uji validitas dan releabilitas.

Data yang digunakan adalah data primer dan data sekunder. Data primer yaitu data yang diperoleh langsung dari responden dan data sekunder adalah data yang diperoleh dari sekolah yaitu jumlah siswa perkelas. 
Pengumpulan data dilakukan secara angket dengan menggunakan kuesioner, dimana responden menjawab setiap pertanyaan yang terdapat dalam kuesioner dan kuesioner ini digunakan untuk melihat hubungan persepsi tentang peran oang tua dengan perilaku seksual siswa tersebut.

Data yang dikumpulkan diberi kode dan di masukkan ke dalam master tabel dan SPSS untuk dilakukan analisa. Analisa univariat dilakukan untuk melihat distribusi frekuensi perilaku seksual remaja dan distribusi frekuensi persepsi tentang peran orang tua tentang perilaku seksual remaja. Analisa bivariat digunakan untuk melihat hubungan persepsi tentang peran orang tua dengan perilaku seksual remaja dengan uji analisis chi square dengan tingkat kepercayaan $95 \%$ dan nilai $p$ value $<0,05{ }^{12,13}$

\section{HASIL PENELITIAN}

\section{Analisa univariat}

a. Perilaku seksual pada siswa SMPN Kabupaten PasamanTahun 2020

\begin{tabular}{|c|c|c|c|}
\hline No & Perilaku Seksual & $\mathbf{F}$ & $\%$ \\
\hline 1 & Beresiko & 189 & 58,4 \\
\hline 2 & Tidak Beresiko & 135 & 41,6 \\
\hline \multicolumn{2}{|c|}{ Jumlah } & 324 & 100 \\
\hline
\end{tabular}

Dari tabel 1 dapat diketahui bahwa dari 324 responden, lebih separoh memiliki perilaku seksual beresiko sebanyak 189 responden (58,4\%).

b. Persepsi tentang peran orang tua tentang perilaku seksual pada siswa SMPN Kabupaten PasamanTahun 2020

\begin{tabular}{|c|c|c|c|}
\hline No & $\begin{array}{c}\text { Persepsi tentang perang } \\
\text { orang tua }\end{array}$ & $F$ & $\%$ \\
\hline 1 & Negatif & 172 & 53,2 \\
\hline 2 & Positif & 152 & 46,8 \\
\hline & Jumlah & 324 & 100 \\
\hline
\end{tabular}

Dari tabel 2 dapat diketahui bahwa dari 324 responden, masih ada responden yang memiliki persepsi tentang peran orang tua yang negatif yaitu sebanyak 172 responden $(53,2 \%)$

\section{Analisa bivariat}

a. Hubungan persepsi tentang peran orang tua dengan perilaku seksual remaja di SMPN Kabupaten PasamanTahun 2020 
Tabel 3. Hubungan Persepsi tentang Peran Orang Tua dengan Perilaku Seksual Remaja SMPN Kabupaten PasamanTahun 2020

\begin{tabular}{|c|c|c|c|c|c|c|c|}
\hline \multirow{3}{*}{ No } & \multirow{3}{*}{$\begin{array}{l}\text { Persepsi tentang } \\
\text { peran orang tua }\end{array}$} & \multicolumn{4}{|c|}{ Perilaku Seksual } & \multirow{2}{*}{\multicolumn{2}{|c|}{ Total }} \\
\hline & & \multicolumn{2}{|c|}{ Beresiko } & \multicolumn{2}{|c|}{ Tidak Beresiko } & & \\
\hline & & f & $\%$ & $f$ & $\%$ & f & $\%$ \\
\hline 1 & Negatif & 130 & & 42 & 24,5 & 172 & 100 \\
\hline 2 & Positif & 59 & 38,8 & & 61,1 & 152 & 100 \\
\hline & Total & & & & & 32 & 100 \\
\hline
\end{tabular}

Dari tabel 3 didapatkan bahwa dari 172 responden yang mempunyai persepsi tentang peran orang tua yang negatif, yang berperilaku seksual beresiko sebanyak 130 responden (75,6\%), dan dari 152 responden yang mempunyai persepsi tentang peran orang tua yang positif didapatkan 59 responden (38,8\%) yang mempunyai perilaku seksual yang beresiko. Setelah dilakukan uji chi square didapatkan hasil $p=0,001$, berarti dapat disimpulkan terdapat hubungan persepsi tentang peran orang tua dengan perilaku seksual remaja di SMPN Kabupaten PasamanTahun 2020.

\section{PEMBAHASAN}

\section{Analisa univariat}

a. Perilaku seksual remaja di SMPN Kabupaten Pasaman

Dalam penelitian ini didapatkan responden yang berperilaku seksual beresiko sebanyak 189 responden (58,4\%). Perilaku seksual yang paling banyak adalah berciuman dengan pasangan yaitu (58,9\%). Responden yang memiliki perilaku seksual beresiko ini menunjukkan bahwa dorongan seksual yang ada dalam diri responden tidak terkontrol dengan baik. Hal ini di sebabkan karena kurangnya peran orang tua terhadap perilaku seksual remaja.

Remaja yang mempunyai perilaku seksual yang beresiko ini akan memberikan dampak yang kurang baik pada dirinya sendiri maupun orang disekitarnya. Jika seseorang memiliki perilaku seksual yang beresiko maka akan berpengaruh pada kesehatan reproduksi, mental dan spiritualnya nanti. Hal ini juga sangat berpengaruh pada perilaku teman-teman yang lainnya, karena pada masa remaja merupakan masa yang cenderung meniru dan tak mau dianggap kuno oleh teman-temannya. Sehingga mereka akan cenderung berperilaku seperti teman-temannya, baik yang positif maupun yang negatif.

b. Persepsi tentang peran orang tua tentang perilaku seksual remaja di SMPN Kabupaten Pasaman

Dalam penelitian ini didapatkan responden yang mempunyai persepsi tentang peran orang tua negatif yaitu sebanyak 172 responden (53,2\%). Dimana sebagian besar responden menjawab orang tua mereka tidak menyediakan waktu bagi mereka untuk 
membicarakan masalah seks yang disebabkan karena masalah seks masih dianggap tabu dan orang tua tidak tau cara menyampaikannya kepada anak-anaknya.

Sehingga menyebabkan anak-anak tidak dapat mengontrol perilaku seksnya yang kebanyakan mengalami perilaku seksual beresiko. Apabila orang tau mampu memberikan pemahaman mengenai perilaku seksual kepada anak-anaknya, maka anak-anaknya cenderung mengontrol perilaku seksnya itu sesuai dengan pemahaman yang diberikan oleh orang tuanya.

\section{Analisa Bivariat}

Hubungan persepsi tentang peran orang tua dengan perilaku seksual remaja di SMPN Kabupaten PasamanTahun 2020. Dalam penelitian ini diketahui bahwa dari 172 responden yang mempunyai persepsi tentang peran orang tua yang negatif, yang berperilaku seksual beresiko sebanyak 130 responden $(75,6 \%)$ dan dari 152 responden yang mempunyai persepsi tentang peran orang tua yang positif didapatkan 59 responden (38,8\%) yang mempunyai perilaku seksual beresiko. Setelah dilakukan uji chi square didapatkan hasil $p=$ 0,001 , berarti dapat disimpulkan terdapat hubungan persepsi tentang peran orang tua dengan perilaku seksual remaja di SMPN Kabupaten PasamanTahun 2020.

Penelitian ini sejalan dengan penelitian Dian tahun 2014 dengan hasil bahwa terdapat hubungan peran orang tua dengan sikap remaja tentang seks bebas dengan $p$ value $=0,001$ $(p<0,05) .{ }^{14}$ Penelitian lain yang juga sejalan dengan penelitian ini yaitu penelitian yang dilakukan oleh Rahma tahun 2019 dengan hasil bahwa tedapat hubungan antara peran orang tua terhadap sikap remaja dalam perilaku seksual remaja dengan $p$ value $=0,000$ $(\mathrm{p}<0,05) .{ }^{15}$

Hal ini terjadi karena di daerah ini membicarakan masalah seksual masih dianggap tabu bahkan kepada anak sendiri. Hal ini terlihat dari bedah kuesioner sebagian besar orang tua tidak menyediakan waktu bagi remaja untuk membicarakan masalah seks. Sehingga ketika remaja tersebut mempunyai pasangan dan timbul hasrat seksual maka mereka akan sangat sulit mengendalikan diri untuk tidak melakukan perilaku seksual yang beresiko. Orang tua mampu mengontrol anaknya dalam berbagai hal, namun orang tua tidak membicarakan atau memberitahu mengenai masalah seksual kepada anak-anaknya, sehingga remaja dalam perkembangannya akan mencari informasi sendiri dan cenderung meniru kepada temantemannya. Faktor lain penyebab remaja melakukan perilaku seksual beresiko adalah pengaruh teman sebaya dan media massa.

\section{SIMPULAN DAN SARAN}

Sebagian besar perilaku seksual remaja di SMPN Kabupaten Pasaman tahun 2020 kategori beresiko yaitu sebanyak 189 responden $(58,4 \%)$. Sebagian besar persepsi tentang 
peran orang tua tentang perilaku seksual remaja di SMPN Kabupaten Pasamantahun 2020 kategori negatif yaitu sebanyak 172 respoden (53,2\%). Terdapat hubungan persepsi tentang peran orang tua dengan perilaku seksual remaja di SMPN Kabupaten Pasamantahun 2020 ( $p$ value 0,001$)$.

Saran peneliti agar kepala sekolah bekerja sama dengan tenaga kesehatan untuk untuk memberikan promosi kesehatan yang menekankan tentang dampak perilaku seksual, dampak penyakit menular seksual dan cara mengalihkan dorongan dan hasrat seksual serta menjalankan PIK remaja.

\section{DAFTAR PUSTAKA}

1. Medise, Bernie. E, dkk. 2017. Promosi dan Konseling Kesehatan Reproduksi Bagi Kelompok Kegiatan Pik Remaja. Jakarta: Direktorat kesehatan reproduksi dan badan kependudukan dan keluarga berencana nasional

2. Badan Kependudukan dan Keluarga Berencana Nasional. 2017. BKKBN Kampanye Kesehatan Reprouksi di Sail Sabang. (https://www.bkkbn. go.id/detailpost/bkkbnkampanye-kesehatanreproduksi-di-sail-sabang) diakses 01 Desember 2019

3. WHO. 2016. WHO Recommendations on Adolescent Sexual and Reproductive Health and Rights. Geneva: World Health Organizations

4. Hargiati, Iqriah. A. 2016. Hubungan Pola Asuh Orang Tua dengan Perilaku Seks Pranikah Pada Remaja Usia (15-18 Th) Tahun di SMA X Bandung. Jurnal Ilmu Keperawatan. Vol. 4 No.2. Bandung: Universitas BSI

5. Badan Kependudukan dan Keluarga Berencana Nasional. 2017. BKKBN Kesehatan Reproduksi dan Nikah dini. (https://www.bkkbn.go.id/ detailpost/kesehatanreproduksi-dan-nikah-dini) diakses 13 Januari 2020

6. Ahiyanasari, Citra. E, nurmala I. 2017 . Niatan Siswi SMA untuk Mencegah Seks Pranikah. Jurnal Promkes. Vol. 5 No.1 Tahun 2017; 36-47. Surabaya: Universitas Airlangga

7. Badan Kependudukan dan Keluarga Berencana Nasional. 2017. BKKBN Mengurustamakan Pembangunan Keluarga. (https://www.bkkbn.go.id/ detailpost/mengurustamakan-pembangunan-keluarga) diakses 13 Januari 2020

8. Badan Kependudukan dan Keluarga Berencana Nasional. 2017. BKKBN Kasus HIV/ AIDS di Kalangan Ibu Rumah Tangga Meningkat. (https://www.bkkbn.go.id/detail post/kasus-hiv-aids-dikalangan-ibu-rumah-tangga-meningkat) diakses 13 Januari 2020

9. Mpondo, Feziwe, dkk. 2018. Understanding the role played parents, culture and the school curriculum in socializing young women on sexual health issues in rural South African communities. South Africa: Informa UK Limited, trading as Taylor \& Francis Group 
10. Dwi hartanto, dkk. 2014. Persepsi Remaja tentang Seks Pranikah Di Desa Tambaklelo Tempel Sleman Yogyakarta. Fakultas ilmu kesehatan. Skripsi. Surakarta: Universitas Muhammadiyah Surakarta

11. Muflih, Muflih dan Endang Nurul Syafitri. 2018. Perilaku Seksual Remaja dan Pengukurannya dengan Kuesioner. Jurnal Keperawatan Respati Yogyakarta . September 2018,438-443. Yogayakarta: Universitas Respati Yogayakarta

12. Notoadmojo, Soekidjo. 2010. Metodelogi Penelitian Kesehatan. Jakarta: Rineka Cipta

13. Hastono, Sutanto P. 2011. Modul Analisis Data Kesehatan. Depok: FKM UI

14. Lutfianawati, dian. 2014. Hubungan Peran Orang Tua dengan Sikap Remaja tentang Seks Bebas. Jurnal Ners dan Kebidanan, Vol 1 No 3. Blitar: Stikes Patria Husada Blitar

15. Hartono, Rahma Akira Pia. 2019. Hubungan Peran Orang Tua dengan Sikap Remaja tentang Perilaku Seksual pada Siswa Kelas XI di SMA N 7 Yogyakarta Tahun 2019. Skripsi. Yogyakata: Politeknik Kesehatan Yogyakarta 